\title{
Pentingnya untuk mengetahui seberapa penting profesi keguruan itu PROFESI KEGURUAN
}

\author{
Lala Sapitri \\ Email: lalasaputri789@gmail.com \\ Program Studi Pendidikan Sejarah Fakultas Keguruan dan Ilmu Pendidikan \\ Universitas Lambung Mangkurat
}

Banjarmasin

\begin{abstract}
Abstrak
Guru mempunyai peranan yang amat strategis dan urgen dalam keseluruhan upaya pendidikan.hampir semua usaha pembaharuan di bidang kurikulum dan penerapan metode mengajar guru, pada akhirnya tergantung pada guru itu. Guru ialah orang merencankan dan melaksanakan proses pembelajaraan, menilai serta mebimbing peserta didik untuk meraih cita cita dan memiliki budi pekerti. Profesi guru merupakan profesi yang dapat menentukan masa depan bangsa ini, guru tanpa mengusi bahan pelajaraan, strategi pembelajaarn mendorong siswa belajar untuk mencapai prestasi yang tinggi. Guru yang profesional minimal memiliki komitmen kepada peserta didik dalam proses belajarnya, guru sering dijadikan tokoh teladan dan bahkan menjadi tokoh identifikasi diri. Dalam melaksanakan tugas profesinya secara baik. Profesi dapat diartikan sebagai suatu pekerjaan atau jabatan yang menuntut keahlia, yang didapat melalui pendidikan atau latihan tertentu. Perkerjaan yang bersifat profesional berbeda dengan perkerjaan lannya karena suatu profesi memerlukan kemampuan dan keahlian khusus dalam melaksanakan profesinya, profesi juga diartikan sebagai suatu jabatan atu perkejaan tertentu yang mensyarakan pengetahuan dan keterampilan khusus yang diperoleh dari pendidikan akademis yang intensif. Jadi profesi guru adalah suatu pekerjaan atau jabatan yang menuntut keahlian tertentu artinya suatu pekerjaan atau jabatan yang disebut profesi tidak dapat dipegang sembarangan orang, tetapi memerlukan persiapaan khusus melalui pendidikan dan pelatihan secara khusus.
\end{abstract}

\section{PENDAHULUAN}

Profesi guru

Berdasarkan UU RI .14 tahun 2005 tentang guru dan dosen pasal 1.profesi pada hakikatnya adalah suatu pernyataan atau suatu janji terbuka yang menyatakan bahwa seseorang itu mengabdikan dirinya pada suatu jabatan atau pelayanan karena orang tersebut merasa terpanggil untuk menjabat pekerjaan itu . Berdasarkan pengertian diatas . meskipun profesi adalah karir seumur hidup dan ada konsekuensi Ekonomis atas pekerjaan di bidang profesi tersebut ,akan tetapi fokus utamanya terletak pada pengabdian dan bertanggung jawab moralnya sesuai bidang keilmuan profesi .

\section{ATRIBUT PROFESI GURU}


Kode etik penting untuk suatu profesi? Karena dengan adanya kode etik ini dapat menghindari dari tindakan tindakan

Yang semena mena atau melakukan perbuatan asusila kepada peserta didik

Yang diajari. Tujuan adanya kode etik untuk profesi ini adalah
a. Menjunjung tinggi martabat profesi
b. Menjaga dan memelihara kesejahteraan
c. Meningkatkan pengabdian para anggota profesi
d. Meningkatkan mutu profesi
e. Meningkatkan mutu organisasi profesi

Kode etik memiliki fungsi perlindungan dan Pengembangan profesi?

A. Agar terhindar dari penyimpangan tugas yang menjadi tanggung jawabnya

B. Untuk mengatur hubungan guru dengan murid, teman sekerja, masyakat, dan Pemerintah

C. Pemberi arah dan petunjuk yang benar kepada mereka yang menggunakan profesinya Dalam melaksanakan tugas.

\section{GURU DAN INSPIRASI KEMAJUAN PENDIDIKAN INDONESIA}

Tugas guru tidak hanya sebagai suatu profesi, tetapi juga sebagai suatu tugas kemanusian dan kemasyarakatan. Misi utamanya guru itu menuntut kepada guru untuk mengembangkan profesionalitas diri sesuai perkembangan ilmu pengetahuan dan teknologi, mendidik, mengajar, dan melatih anak didik adalah tugas guru sebagai suatu profesi. Tugas guru sebagai pendidik berati meneruskan dan mengembangkan Nilai nilai hidup kepada peserta didik.

Guru guru harus menanamkan nilai nilai kemanusiaan kepada peserta didik, pada Bidang ini guru mempunyai tugas mendidik dan mengajar masyarakat menjadi warga Negara indonesia yang bermoral pancasila

Peranan guru : 
1. Korektor

2. Inspirator

3. Informan

4. Organisator

5. Motivator

6. Inisiator

7. Fasilitator

8. Pembimbing

9. Demonstrator

10. Pengelola kelas

11. Mediator

12. Supervisor

13. Evaluator

Kewajiban guru :

1. Merencanakan pembelajaraan, melaksanakan proses pembelajaran yang bermutu, serta menilai dengan mengevaluasi

2. Mengembangkan dan meningkatkan kualifikasi akademik dan kompentensi secara Berkelanjuttan sejalan dengan perkembangan ilmu pengetahuan dan teknologi seni. Bertindak objektif dan tidak diskriminatif atas dasar pertimbangan jenis kelamin, Agama, ras, suku, dan kondisi fisik tertentu atau latar belakang keluarga dan status Sosial ekonomi peserta didik dalam pembelajaraan.

3. Menjunjung tinggi peraturan perundang undangan, hukum dan kode etik guru, serta Nilai nilai agama etika.

4. Memelihara dan memumpuk persatuan dan kesatuan bangsa.

5. Menyerahkan kebudayaan kepada anak didik berupa kepandaian kecakapan dan Pengalaman pengalaman

6. Membentuk kepribadian anak yang harmonis, sesuai cita cita dan dasar negara kita Pancasila 
7. Menyiapkan anak menjadi warga negara yang baik sesuai dengan undang undang Pendidikan

Memaknai filosofi pendidikan Indonesia "Ing ngarso Sung tulodo, ing madya mangun karso, tutwuri handayani"

A. Role model (ing ngarso tulodo)

Memberikan teladan kepada siswa karena fungsi guru menjadi pemimpin Siswa dalam kegiatan pembelajaraan.

B. Motor penggerak (ing madya mangun karso)

Guru harus menjadi penggerak inovasi dalam proses pendidikan dan penggerak Peradaban dengan cara mengarahkan sisa untuk melakukan yang benar.

C. Motivator (tutwuri handayani)

Mampu memberikan dorongan semangat kepada siswa untuk mengadapi setiap Persoalan dan mempelajari nilai nilai kehidupan

\section{SIMPULAN}

Profesi guru merupakan profesi yang sangat penting dan berkontribusi langsung terhadap kemajuan suatu bangsa .sebagai suatu profesi , guru idealnya memiliki syarat-syarat khusus untuk dapat dijalani seseorang .

\section{REFERENSI}

Barnawi \& Arifin, M. (2014). Etika dan profesi kependidikan. Yogyakarta Ar-Ruzz Media

Bigge, M.L. (1963) learning theories for teacher new york: harper \&

Row

Danim, S.(2015) pengembangan profesi guru dari prajabatan, induksi ke profesional

Madani. Jakarta: prenadamedia group

Darajat, Z (2005) kepribadiaan guru (edisi VI)

Jakarta bulan bintang

Hermawan, S.R. (1979) Etika keguruan: suatu pendekatan terhadap kode etik guru indonesia 
Mutiani, M., Abbas, E. W., Syaharuddin, S., \& Susanto, H. Membangun Komunitas Belajar Melalui Lesson Study Model Transcript Based Learning Analysis (TBLA) dalam Pembelajaran Sejarah. Historia: Jurnal Pendidik dan Peneliti Sejarah, 3(2), 113-122.

Mutiani, M., WARMANSYAH ABBAS, E. R. S. I. S., Syaharuddin, S., \& Susanto, H. (2019). Penerapan Transcript Based Lesson Analyses (TBLA) Sebagai Upaya Peningkatan Pembelajaran Sejarah Di Sma Negeri 7 Banjarmasin.

Susanto, H. (2020). Profesi Keguruan. Banjarmasin: FKIP Universitas Lambung Mangkurat.

Susanto, H., Irmawati, I., Akmal, H., \& Abbas, E. W. (2021). Media Film Dokumenter Masuknya Islam Ke Nusantara dan Pengaruhnya Terhadap Keterampilan Berpikir Kritis Siswa. HISTORIA: Jurnal Program Studi Pendidikan Sejarah, 9(1). 